\title{
HARMONY BETWEEN ECONOMY AND ENVIRONMENT
}

\author{
Milica Vukićević Petković ${ }^{1}$, Jasmina Šmigić Miladinović ${ }^{2}$ \\ 12 Kosovo and Metohija Trades Academy
}

Corresponding: vmilica84@gmail.com ${ }^{1}$

Review article

Received: 15.10.2020; Accepted: 10.12.2020

\begin{abstract}
Since the environment surpasses all the frames created by men, the basic aim of this paper is to point to how important the quality of the environment is, as well as to discuss whether the two, protection of the environment and economy endorsement, can function together. The economy which does not respect natural resources in an adequate way is irrational. That is why the importance of social awareness of the environment's sacrificing for the purpose of economic progress is underlined. It is not always sufficient to abandon everything to various interests, and thus secure the most favourable economic status, but it is also necessary to refocus people's economic functioning to the promotion of the environment. This paper analyses economy's essential functions production, distribution, exchange, and consumption which, on the one hand, have an impact on the exploitation of natural resources, and on the other bring about waste generation. Only a correct treatment of waste may produce multiple benefits.
\end{abstract}

Keywords: environment protection, economic activities, "green occupations", legal regulations.

\section{Introduction}

Protection of the environment issue usually gets less attention, for people deal with numerous economic problems, especially unemployment, on a daily basis. The environment and economy issues complement each other. In the $21^{\text {st }}$ century, protection of the environment is a field which experiences a significant development and brings about changes in the labour market. In Europe and in the world, where people are more ecologically conscious than we are, there is already a number of so- $^{-}$ called "green occupations", such as green construction engineers, workers specially trained for water energy and so on. With economy's incorporation of green technologies, the environmental expenses are reduced through effective use of 
Vukićević Petković M. et al., Harmony between economy and environment

resources, while new technologies and skills open possibilities and stimulate economy at the same time. The state has a leading role in the sphere of protection of the environment, and economic entities also have an important role. Any decision which contributes to preservation of the environment, and represents a right and honest intention of economic entities in the process, stands for a change in consciousness of appraisal of natural resources.

\section{Role of economy in the sphere of protection of environment}

Given the fact that economy's basic functions are realised within the environment, this leads to association between economy and the environment in the form of use of natural resources for the needs of production and consumption. Household is a basic consumption unit, which, in modern living circumstances, increases consumption activities, and by doing so also increases the quantity of waste. Therefore, a production process comprises matter and energy, the waste being a side-effect. Pollution is an old phenomenon of the development of humanity, and today it is present as production and consumption-related pollution of air, water, and soil. The conse- quences of pollution are already visible, and they can be felt everywhere - from dirty streets and parks to climatic changes.

As for the waste collection system, it is necessary to begin with, as soon as possible, classification of packing waste according to materials, as well as develop recycling and rubbish pit systems. By recycling the waste, plants, natural resources and wildlife are preserved; air, water and soil pollution is reduced; the soil energy is saved, and rubbish pits' duration extended. People may also become richer by recycling, because it stimulates economic development and influences new job openings. Over the years, ever larger waste quantity is generated, and is disposed of in municipal rubbish pits without having been treated beforehand. Such a practice makes it impossible to make use of waste resources, and it actually means a great loss of resources and a risk to the environment and people's health.

All countries, aspiring to become members of the European Union, have to harmonise their legislation, regulations and procedures with the legislation contained in the socalled "acquis communautaire". In one of the largest (territory-wise) municipalities in the north of Kosovo, even though there is an 
existing public utility company, many wild rubbish pits have been noticed. Perhaps this problem could be solved by investing more in utility services, which are of immense importance for the pro- $^{-}$ motion of quality of the environment. Utility services can be improved through constant investments in development, as well as by modernising existing capacities by means of application of new technologic solutions in order to provide its clients with more diverse and better quality services. Furthermore, by introducing modernisation and new technologic solutions, opportunities are created for new jobs. That is why a company's management should be offered adequate solutions which are economically and ecologically justified. "Green jobs", contributing to changes in the labour market in the form of new job openings, are realised not only through maintenance of municipal infrastructure, green spaces and forests, but also through new jobs in sustainable tourism, fishing, food production etc.

Therefore, a staff properly qualified in accordance with global and national trends has been understood as one of the main prerequisites to development of the sphere of promotion and protection of the environment.

\section{Interventions in sphere of environment protection}

Due to irresponsible pollution and negligent treatment of nature, protection of the environment has become an extremely important part of modern people's lives. These very reasons impose, as an essential task for the modern society, a need to preserve the values and particular features of the environment. It includes activities within the field of legislation and establishment of a legal system which should both provide and effectively regulate reduction of the existing pollution, as well as prevent a future one. Moreover, the creation of an efficient legal system is usually accompanied by participation of the broadest public in the procedures of implementation and adoption of ecologic regulations. Given that protection of the environment is a long-term aim in the development of the modern society, then all members of society, from an individual to the highest state institutions, should take part in its fulfilment. Persons may take part in legal or other kind of protection if they have been informed properly, which can solely be done with ecologic data available. That leads to a conclusion that successful interventions in the sphere of protection of the envi- 
Vukićević Petković M. et al., Harmony between economy and environment

ronment may be carried out only by including all concerned parties.

Educators, teachers, and professors have an opportunity and obligation to influence the children they teach through their personal examples. Medical sector, on the other hand, can be of much help in the process by promoting a healthy environment as a basic condition for improvement of quality of life and health.

The environment is a complex term which comprises nature and its surroundings, as well as essential natural elements - air, water, and soil, including energy, material goods and cultural heritage as parts of the surroundings created by men by means of labour and mind. [Bjelajac et al., 2012] The increase of human population has as a result a rise in production and overconsumption, which, then, leads to accumulation of large quantities of waste, and finally to an environmental imbalance. The imbalance is caused through accumulation of waste and its irresponsible disposal. Nowadays, there are dangerous kinds of waste, such as chemical, biological, or radioactive ones. The radioactive waste is seen as particularly dangerous, due to its extremely long period of disintegration, as well as long-term and harmful consequences. The risk from this type of waste has been constantly increasing with rising numbers of nuclear plants, devices or engines which function by means of radioactive sources, that is materials emitting ionising radiation (Ionising Radiation Protection and Nuclear Safety of Serbia Law).

Both the environment and human population have been suffering from ever more obvious and heavier consequences of pollution. Only a healthy workforce can take part in production. Good health enables the workforce to be productive, which increases a community's capabilities to develop human capital, carry out economic activities, or attract investments. [Sachs, 2014] According to legal regulations, the environment is defined as a group of natural and created values, whose complex interrelations include surroundings, space and living conditions, respectively (Environmental Protection Law). The issue of the environment and its protection can be viewed from many different aspects, such as economical, ethical, ideological, globalisational and so on, and it encompasses various procedures and measures. [Todic, 2017] An economic system is unsustainable in the long term if it does not value natural resources adequately, and, despite limited resources, stimulates unlimited economic growth. The relationship between economy 
and ecology is characterised by certain opposites, but it is vital to find their mutuality. [Trivic, 2007] Natural surrounding for the man's economic activity is a concern of the study and where resources are found. Economic activity of people and technologic development make use of nature's living and nonliving things as a gift. From the standpoint of economic activity, nature is a free resource. [Trivic, 2007] Refocusing of people's economic behaviour is necessary, so that the system of human values and institutions can impact shaping of the system of supply and demand towards promotion of the environment.

\section{Our country's ecology policy}

Ecology policy is a special policy which deals with orienting the society and people's relations towards nature, and its essential and final goal is preservation, protection, and promotion of the environment, through the agency of our state, as well as social and political organisations. Ecology policy's entities are: state, economic entities, academic institutions and professional organisations for environmental protection, political parties, various organised groups of citizens. [Markovic, 2005]
Institutionalisation of ecology policy in Serbia began in 1989, with creation of the Republic secretariat for environmental protection. As a member of the FRY, the Republic of Serbia conducted an independent policy in the sphere of environmental protection. Obligations resulting from international treaties signed by the SFRY and the FRY were successively transferred to federal states, members of the republic, which were fully authorised to regulate through their legislations the sphere of protection of the environment. [Nadic, 2012] Regarding the environment, legal obligations in the world and in our country have become more significant, and they represent an unavoidable factor for any future activity. Essential regulations from the field of environmental protection, which represent the basis for adoption of other important ecology laws and acts are: Integrated Pollution Prevention and Control Law, Environmental protection Law, Strategic Environmental Assessment Law, and Environmental Assessment Law. These laws have been harmonised with EU ecology acts, namely with EU directive on environmental assessment (85/337/ EEC), strategic assessment (82001/ 43/EC), IPPC (96/61/EC) and public participation (2003/35/EC). [Nadic, 2012] 
Vukićević Petković M. et al., Harmony between economy and environment

When talking about enterprises as entities of ecology policy, one should bear in mind that the constitution of our country states that entrepreneurship is free, but may be limited by law for reasons of protection of the environment, people's health, and natural $\mathrm{re}^{-}$ sources. Possibilities with a number of different factors have been determined for an effective application of management instruments in the environmental field. This is mostly related to the nature of business, as well as a branch of economy, along with rights and obligations which the entities have on the basis of regulations in the sphere of the environment. Being conditional on business with certain foreign-economic circumstances might have a great influence, too. In addition to the classic orientation towards the rise in profit and growth of their organisations, contemporary enterprises should take into consideration protecting the environment from negative impacts of economic activities. Furthermore, all economic entities are obliged to obey ecology-related legal regulations with the view of protecting the environment.

\section{Conclusion}

Successful interventions in the environmental protection field cannot be realised by involving only one sector - they need participation of all concerned parties. It is a longterm goal, the realisation of which should include all societal factors, from an individual up to the highest state institutions.

Numerous and diverse causes bring about pollution and deterioration of the environment, and many of them are human-related. Irresponsible human behaviour in correlation with other factors produces harmful effects which lead to break-outs of ecologic crises. Both the environment and human population have been suffering from ever more obvious and heavier consequences of pollution. Only a healthy workforce can be productive, and develop human capital and carry out economic activities. For these reasons, contemporary enterprises have to be cautious not to harm the environment with their activities, and not only think about profit rise. Even though the constitution of the Republic of Serbia states that entrepreneurship is free, it may be limited by law for reasons of protection of the environment. Economy is irrational if it does not respect natural resources adequately. It is necessary to create awareness of the environmental sacrificing for the purpose of economic progress.

Protection of the environment and economic endorsement may coexist, 
for the very environmental policy has a key role in creation of new job openings. In the world, where people are more ecologically conscious than we are, there is already a number of so-called "green occupations". With economy's incor-

\section{References}

Bovan, A.B, Barać, Stojanović, A. (2014), CEDEF Guide - Recommendations for municipal and industrial waster management in Belgrade and the Republic of Serbia, Belgrade, Central European Development Forum

Bjelajac, Ž,. Počuča, M. Marković, M., (2012) EU policy in fields of environmetal protection with focus on criminal legal aspects and role of family in environmental raising awareness, Belgrade, Foreign Legal life, 32012, 540

Despotović, Lj,. (1993) Ecology as criticism of modernism, Novi $\mathrm{Sad}$

Djukanović, M. (1996), Environment and sustainable development, Belgrade, Elit

Golić, B., (2005) Ecology and ecological law, Sarajevo

Gorz, A., (1982) Ecology and politics, Belgrade, Prosveta poration of green technologies, the environmental expenses are $\mathrm{re}^{-}$ duced through effective use of $\mathrm{re}^{-}$ sources, while new technologies and skills open employment possibilities and stimulate economy at the same time.

Jonathan, H.M (2009) Environmental and Natural Resource Economics: A Contemporary Approach, second edition, translation, Belgrade

Keković, Z. (1999) National Security and Environment, Belgrade, Andrejević Legacy

Marković, D., Ilić, B., Ristić, Ž., (2010), Ecological economics, Belgrade

Milenković, D., (2006), Collection of regulations in the field of environmental protection, Belgrade, Službeni glasnik (Official Journal)

Miltojević, D.B., (2004) Ekological culture, Niš, Faculty of Occupational Safety

Nadić, D., (2009), Ecological Modernization Theory, Belgrade, Faculty of Political Sciences

Nadić, D., (2012) Political ecology experiments, Belgrade, Faculty of Political Sciences 
Vukićević Petković M. et al., Harmony between economy and environment

Nadić, D., Šuvaković, U., (2011) National Sustainable Development Strategy of the Republic of Serbia, political version or utopia, Belgrade, Ecologica, No 62, XVIII, 161-167

Radojević, D., (2011) A roadmap to sustainable development, Belgrade, Ministry of science and technological development

Saks, Dž.D., (2014) Sustainable Development Era, Belgrade, JP Official Journal

Šuvaković, U., (2009) The world in change: political violence and the global environmental crisis, Belgrade, Ecologica, year XVI, number 55
Tadić, V., Vuksanović, V., (1999) International organizations and international cooperation in field of environmental protection, Novi Sad

Todić, D., (2007) Sustainable development and environment policy and law principles, Belgrade, Legal life, number 9/2007, 430

Trivić, N., (2014) Economics and ecology: unity and/or opposition, Subotica, Annals of the Faculty of Economics, No 14, 123

Živković, T., (2014) Harmonization of national regulations on environmental protection with the European Union laws, Legal annals, Vol 1, 197-216

Law on Environmental protection (Official Journal of the Republic of Serbia, number 135/2004, 36/2009, 36/2009) 


\section{SKLAD PRIVREDE I ŽIVOTNE SREDINE}

\section{Milica Vukićević Petković ${ }^{1}$, Jasmina Šmigić Miladinović ${ }^{2}$}

12 Akademija Kosovsko Metohijska, odsek Peć u Leposaviću, Leposavić

Korespondencija: vmilica84@gmail.com ${ }^{1}$

Rezime: Budući da životna sredina prevazilazi sve okvire koje je stvorio čovek, osnovni cilj rada je da se ukaže na značaj kvaliteta životne sredine kao i na pitanja da li zažtita životne sredine i podrška privredi mogu da idu jedno s drugim. Privreda koja ne poštuje prirodne resurse na adekvatan način je neracionalna. Zato se i ističe značaj društvene svesti o žrtvovanju životne sredine zarad ekonomskog napretka. Nije uvek dovoljno da se stvari prepuste interesima i da se taj našin obezbedi najpovoljnije ekonomsko stanje, potrebno je preusmeriti okonomsko ponašanje ljudi u smislu unapređivanja životne sredine. U radu se analiziraju osnovne funkcije privrede, proizvodnja, distribucija, razmena i potrošnja, koje $\mathrm{s}$ jedne strane utiču na iskorišćavanje prirodnih resursa dok $\mathrm{s}$ druge strane dovode do stvaranja otpada. Samo pravilan odnos prema otpadu mogao bi svima da donese višestruke koristi.

Ključne reči: zaštita životne sredine, privredne delatnosti, "zelena zanimanja", pravna regulativa. 